\title{
Intellectual capital and islamic corporate social responsibility on the financial performance of sharia commercial banks in Indonesia
}

\author{
Rahayu $\mathrm{Sri}^{1 *}{ }^{*}$, Fauzi Mahdi ${ }^{1}$, Julkarnain ${ }^{1}$, Ningsih Heny Triastuti Kurnia ${ }^{1}$, Azwansyah Habibie ${ }^{2}$ \\ ${ }^{1}$ Universitas Islam Sumatera Utara, 20217, Indonesia \\ ${ }^{2}$ Universitas Harapan, Medan
}

\begin{abstract}
This study aims to examine Intellectual Capital, Islamic Corporate Social Responsibility on the Financial Performance of Islamic Commercial Banks in Indonesia based on the Islamicity Performance Index. The dependent variable is the Financial Performance of Islamic Commercial Banks in Indonesia based on the Islamicity Performance Index. The independent variables used in this study are Intellectual Capital and Islamic Corporate Social Responsibility. The population in this study is 14 Islamic banking companies. The sampling technique used purposive sampling, as many as 8 Islamic banking 2016-2019. The data were analyzed using Partial Least Square (PLS) tools. General Sharia based on Islamic City Performance Index with indicators of Equitable Distribution Ratio and Profit Sharing Ratio. Islamic Corporate Social Responsibility has no effect on the Islamic City Performance Index with indicators of Equitable Distribution Ratio and Profit Sharing Ratio.
\end{abstract}

\section{Introduction}

Since their inception in the mid-1970s, Islamic banks have expanded into the majority of the world's financial markets. Based on the theoretical point of view of Islamic banks, based on the principle of profit and loss sharing, instead of interest-bearing deposits or loans found in conventional banks, two conflicting legal views emerge in modern Islamic banks. According to conventional financial practice, the Islamic banking system should change the old contract by strictly incorporating Islamic business practices and social responsibility into banks [1]. The objective of Islamic banks is to promote and develop the application of Islamic principles in financial, banking and related business transactions.

Management of Islamic banks eliminates cruelty and injustice in the financial system due to usury and ensures economic development by introducing halal businesses [2]. Islamic banks are better in deposit growth business development, profitability, liquidity and solvency, asset quality, capitalization solvency of financial stability, risk, cash, cash deposits ratio and financial stability [3]; [4].

Competing in today's business world is becoming increasingly difficult. This condition necessitates that every company consider its competitors when developing company strategies and carrying out activities, so that company goals can be met, which can ultimately reflect good company performance. The achievement of peak performance is unquestionably desired by the company's management as well as its shareholders. One performance that we can see is the financial performance, financial performance is a measure of the success of management in carrying out activities or operational company. It is also inseparable from the banking sector which has a significant impact on the economic development of a country. In any country, banking plays an important role in regulating the economy in its movement and development process. This sector is considered the main factor for the development and success of various industrial and development projects of the country [5].

At present, the growth of the bank sharia in Indonesia has increased rapidly after the enactment of Law No. 21 of 2008 concerning Islamic Banking. This development can be seen from the number of banks and the number of offices of both Sharia Commercial Banks (BUS), Sharia Business Units (UUS), and Sharia People's Financing Banks (BPRS) [6]. Judging from the survey listed on the website of the Financial Services Authority (OJK), the development of Indonesian banking is good and shows quite significant progress. Because within 28 years there have been around 198 sharia banks registered on the OJK site. If in the future the development of Islamic banking continues to show progress, it can be ascertained that Islamic banking will be even bigger as and as big as conventional banks. Based on statistical data from the Financial Services Authority (OJK) the number of Islamic Commercial Banks in Indonesia continues to increase, in January 2015 the number of Islamic Commercial Banks was 12 banks with total assets of 213,423 billion then in December 2019 increased to 14 banks with total assets of 350,364 billion. Conventional banks, the number of banks in 2014 was 118 banks with total assets of 6,095,908 billion, until 2019 the number of banks was 110 banks with total assets of $8,562,974$ billion [7].

The current growth of Islamic banking in Indonesia has not shown positive indicators. The growth rate can be assessed based on the number of banks, the amount of accumulated funds and the value of assets owned, which shows a minimal increase and is significantly different from conventional banking operations. When

${ }^{*}$ Corresponding author: sri.rahayu@fe.uisu.ac.id 
compared to Malaysia, $20 \%$ dominates the Islamic banking market share of $20 \%$, while Indonesia is around $5 \%$ [8]. Various institutions identified the reasons for the slowdown in the development of the Islamic banking sector, one of which was the OJK which stated that the delay was triggered by several things, such as low government support, the value of capital owned by Islamic banks, the structure of Islamic banking funding, products and services that were not varied, the number of quality of human resources and inadequate use of technology, knowledge and public awareness of sharia banking as well as regulation and supervision that is not optimal for sharia banking [9]. Seeing the backwardness of Islamic banking, further analysis is needed to overcome these problems and make Islamic banking a wheel that has the opportunity to boost economic conditions in Indonesia.

Along with changes in the science-based economy and with the application of knowledge management, the prosperity of a company will depend on an achievement of transformation and capitalization of the knowledge possessed by the company. The use of science and technology at this time is known as Intellectual Capital or intellectual capital. Intellectual Capital is the main source of value creation, business performance, and competitive advantage. Knowledge resources in the form of employees, customers, processes or technology which the industry can use in the process of creating value for the company [10]. Intellectual Capital consists of 3 components, namely, human capital, structural capital, and customer capital. The concept of intellectual capital has received much attention in various fields, both in the fields of management, information technology and accounting. This paper discusses the concept of intellectual capital, how to measure intellectual capital, intellectual capital management and how intellectual capital should be reported in financial statement [11].

Several studies related to improving company performance have been carried out previously, including $12,13]$, states that intellectual capital has a positive effect. That Intellectual Capital (IC) has an effect on the company's financial performance. The higher the value of intellectual capital owned by a company, the higher the company's ability to generate profits for the company. So that the higher the Intellectual Capital (IC) value of a company, the ROA is also "higher." Here are some studies on the influence of IC on financial performance as reported by, the variable Intellectual Capital (IC) and the supervisory board sharia (sharia supervisory board) has a positive and significant influence on financial performance". Meanwhile, research conducted by [14] concluded that Intellectual Capital has no effect on the financial performance of companies proxied by the Islam city Financial Performance Index.

The next researcher stated that Islamic Corporate Social Responsibility had an effect on company performance based on the Islam city performance index [15]. Islamic Corporate Social Responsibility is a corporate social responsibility towards all stakeholders based on the values Islamic [16]". Then [17] "found significant positive results related to the relationship between ICSR and company reputation and performance. Research conducted [18] concluded that Islamic Corporate Social Responsibility has no effect on company performance.

The Islam city performance index is a tool for evaluating a company's financial performance based on the materialistic and spiritual values found in the BUS annual report [19]. According to the Islamic finance institution, ICSR may be viewed as an entity that the Muslim community can rely on to channel their funds. [20] so as increase Islamic financial performance.

This study will look at the impact of intellectual capital and Islamic Corporate Social Responsibility on financial performance at Islamic Commercial Banks in Indonesia from 2016 to 2019.

\subsection{Literature review and Hypotheses.}

\subsubsection{Islam city Performance Index (IPI)}

Islamic Banking Performance Evaluation Islam city Performance Index is a performance measurement tool that can reveal the materialistic and spiritual values found in Islamic banks. In a performance measurement method for Islamic banks, financial ratios used by [21, 22].

a. Islamic Income vs. Non-Islamic Income Ratio (IsIR). The measurement scale in the IsIR value uses the ratio scale of Islamic Income divided by Total Income.

b. Equitable Distribution Ratio (EDR). EDR = (Qard + Employees + Net Profit)/ (Revenue$($ Zakat + Tax $))$

c. Zakat Performance Ratio (ZPR). ZPR=Zakat divided by Net Asset

d. Profit Sharing Ratio (PSR). PSR= (Mudharabah Financing + Musyarakah Financing)/Total Financing

\subsubsection{Intellectual Capital (IC)}

Intellectual Capital (IC) is data and information that is applied within the organization to make the organization superior. The IPI scale measurement indicator in this study uses a ratio that has been studied by.

a. Value Added (VA).

Information:

$$
\mathrm{VA}=\mathrm{OUT}-\mathrm{IN}
$$

$\mathrm{VA}=$ Value Added

OUT $=$ Output (total revenue)

IN = Input (total expenses other than employee expenses).

b. Value Added Capital Employed (VACA).

It is the capacity of the organization or association in supervising the assets of capital resources.

VACA $=$ Value Added (VA) divided by Capital Employed (CE)

c. Human Capital (VAHU).

VAHU $=$ Value Added (VA) divided by Human Capital.

d. Structural Capital (STVA). 
It is the capacity of the organization to include data frameworks, authoritative cultural systems, and foundations to assist workers' organizations.

STAVA = Structural Capital (SC)/Value Added (VA) (4)

e. Value Added Intellectual Coefficient (VAIC TM)..

VAIC is the sum of its components, namely VACA, VAHU, and STVA.

IB-VAIC = IB-VACA + IB-VAHU + IB-STVA ${ }_{(5)}$

\subsubsection{Islamic Corporate Social Responsibility (ICSR)}

Islamic "Corporate Social Responsibility (ICSR) is the social, natural and religious responsibility of a company based on Islamic norms in carrying out it. [23] provides an explanation of the indicator research ICSR quality using a 0-3 scale for each indicator information disclosed, namely:

1) Value 0: "if not disclosed in the annual report

2) Value 1: if it discloses, but only provides a statement about the indicator itself without any other explanation.

3) Value 2: if it discloses and there is a qualitative explanation.

4) Value 3: if it discloses and there is a qualitative and quantitative explanation.

ICSR indicators include:

a. Islamic economic responsibility

b. Legal responsibility I slam

c. Islamic ethical responsibilities

d. Islamic Philanthropic Responsibilities

Furthermore, to get the ICSR value, the total ICSR disclosure quality score of each Islamic bank is compared with the total maximum disclosure score. The formula is:

$$
\text { QICSR } \mathrm{i}=I C S R=\frac{\text { SQICSR }}{\text { SQMAX }}
$$

Where: QICSRit : Value of ICSR quality for Islamic commercial banks; iSQICSRi : ICSR quality score of Islamic commercial banks; iSQMAX : Maximum score of ICSR quality

In this study, the researcher determined that there were 2 problem formulations, with three variables, namely 2 independent construct variables $(\mathrm{X})$ and 1 dependent construct variable (Y). To make it easier to understand the flow of data testing, the researchers first designed a structural model. The following is a structural model of the research construct variables as follows:

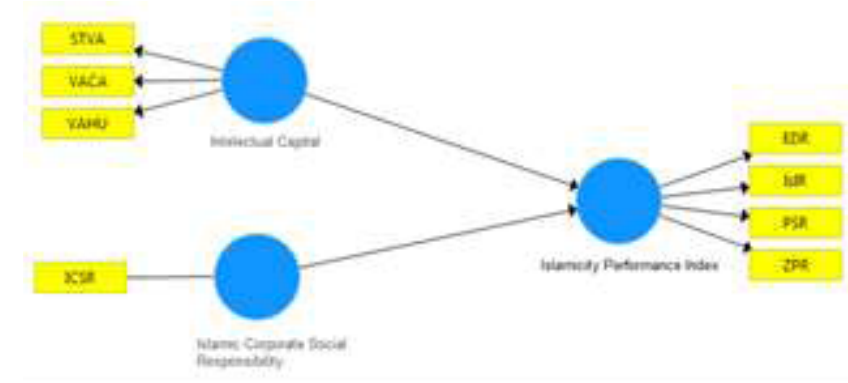

Fig.1.Structural Model with Partial Least

The hypotheses of this research are:

H1 : Intellectual Capital has an effect on financial performance based on the Islam city Performance Index of Islamic commercial banks.

H2 : Islamic Corporate Social Responsibility has an effect on financial performance based on the Islam city Performance Index of Islamic commercial banks.

\section{Research Methods}

\subsection{Population and Sample}

In the study, the population is recorded in the Islamic banking Financial Services Authority (FSA) from 2016 to 2019. This investigation's population consists of 14 Islamic financial organizations. Purposive testing is the examination strategy in this study, and there are 8 organizations that meet the size (providing a total exploration factor and fulfilling the year of investigation) that can be used as examples in this study.

\subsection{Data analysis}

In " this investigation data analysis using Partial Least Square (PLS) and analysis of research data is supported by previous studies that " research [21] using the method of Partial Least Square (PLS).

\section{Results}

\subsection{Outer Model Hypothesis 1}

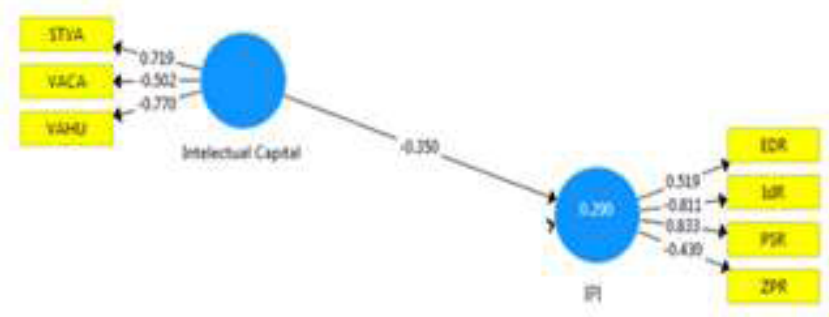

Fig. 2. Structural Model with Partial Least Square H1

From the picture above, it can be seen that the loading factor value of each indicator of the two variables, namely Intellectual Capital and Financial Performance of Syrian Commercial Banks (Islamicity 
Performance Index). There are indicators that have a low and insignificant loading factor value, namely the Value Added Capital Employed (VACA), Value Added Human Capital (VAHU), Islamic Income Vs Non Islamic Income (IsIR) and Zakat Performance Ratio (ZPR) indicators, it is necessary to retest by eliminating insignificant indicators and only involving significant indicators. Shows the consequences of retesting after the markers Value Added Capital Employed (VACA), Value Added Human Capital (VAHU), Islamic Income versus Non-Islamic Income (IsIR) and Zakat Performance Ratio (ZPR) are removed.

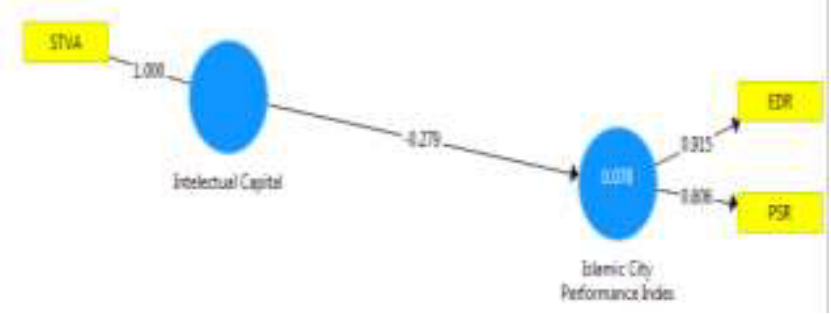

Fig. 3. Structural Model with Partial Least Square H1 (Recalculate)

After eliminating indicators that are not significant and only involve significant indicators, it can be seen that the indicator that has a loading factor above 0.5 is the Structural Capital Value Added (STVA) indicator in the Intellectual Capital variable. Meanwhile, in the Syrian Commercial Bank Financial Performance (Islam city Performance Index) variable, only the Profit Sharing Ratio (PSR) indicator, and the Equitable Distribution Ratio (EDR) have a loading factor value above 0.50 .

\subsection{Discriminant Validity}

Table 1. Value of Discriminant Validity H1 Intelectual Capital Islamicity Performance Index

\begin{tabular}{|c|c|c|}
\hline & $\begin{array}{c}\text { Intelectual } \\
\text { Capital }\end{array}$ & $\begin{array}{c}\text { Islamicity Performance } \\
\text { Index }\end{array}$ \\
\hline EDR & -0.271 & 0.915 \\
\hline PSR & -0.138 & 0.606 \\
\hline $\begin{array}{c}\text { STV } \\
\text { A }\end{array}$ & 1.000 & -0.279 \\
\hline
\end{tabular}

From the table above, it can be seen that each factor related to pointers is higher than the relationship variables with different markers. This shows that dormant factors, particularly Intellectual Capital (IC) and Islam city Performance Index (IPI), anticipate markers in their squares to be higher than other squared markers. For example, in the square of the Intellectual Capital (IC) variable, the value of the pointer in this square is higher than the different factors.

\subsection{Composite Reliability}

Table 2. Composite Reliability H1

\begin{tabular}{|c|c|}
\hline Variable & $\begin{array}{c}\text { Average Extracted Variance } \\
\text { (AVE) }\end{array}$ \\
\hline Intellectual capital & 0.446 \\
\hline $\begin{array}{c}\text { Financial } \\
\text { Performance }\end{array}$ & 0.566 \\
\hline
\end{tabular}

This is indicated by the value of Intellectual Capital Variable composite reliability under 0.50 while the Financial Performance of Commercial Bank sharia (Islam city Performance Index) above 0.5 as the recommended criteria.

\subsection{Outer Test of Hypothesis Model 2}

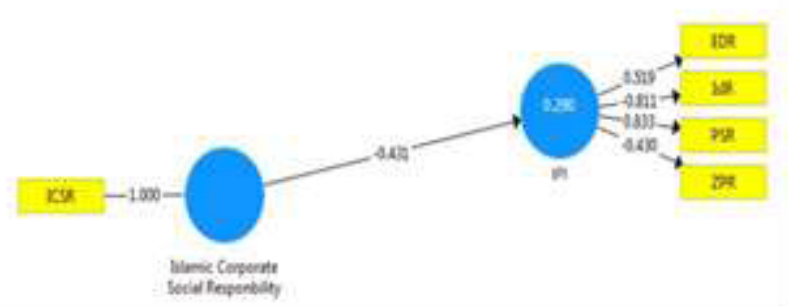

Fig. 4. Structural Model with Partial Least Square H2

From the figure above, it can be seen that the loading factor value of each marker of the two variables is Islamic Corporate Social Responsibility (ICSR) Financial Performance of Universal sharia Bank (Islam city Performance Index). There are markers that have a low and insignificant loading factor value, namely the indicator, Islamic Income Vs. Non Islamic Income (IsIR) and Zakat Performance Ratio (ZPR) so it needs to be retested by eliminating indicators that are not significant and only linking indicators that are not significant. Significantly and only relates significant indicators.

Table 3. Average variance Extracted (AVE).

\begin{tabular}{|c|c|}
\hline Variable & $\begin{array}{c}\text { Average Variance } \\
\text { Extracted (AVE) }\end{array}$ \\
\hline $\begin{array}{c}\text { Islamic Corporate Social } \\
\text { Responsibility }\end{array}$ & 1.000 \\
\hline Financial Performance & 0.566 \\
\hline
\end{tabular}

It is very clear that the marker that has a loading factor above 0.5 is the Islamic Corporate Social Responsibility (ICSR) pointer on the Islamic Corporate Social Responsibility (ICSR) variable. Meanwhile, on the Islam city Performance Index variable, only pointers from Profit Sharing Ratio (PSR) and Equitable Distribution Ratio (EDR) have a loading factor esteem above 0.50 . 


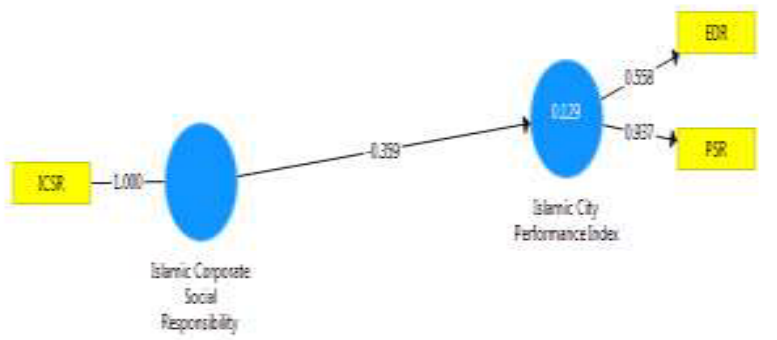

Fig.5. Structural Model with Partial Least Square H2 (Recalculate)

\subsection{Discriminant Validity}

From the table above, it can be seen that each relationship factor with markers is higher than connection variables with different pointers. This shows that the dormant variables, namely Islamic Corporate Social Responsibility (ICSR) and the Financial Performance of Syrian Commercial Banks (Islam city Performance Index), predict that the marker in its square is superior to other squared markers.

Table 4. Value of Discriminant $\mathrm{H} 2$

\begin{tabular}{|c|c|c|}
\hline & $\begin{array}{c}\text { Islamicity } \\
\text { Performance Index }\end{array}$ & $\begin{array}{c}\text { Islamic Corporate Social } \\
\text { Responsibility }\end{array}$ \\
\hline $\begin{array}{c}\text { ED } \\
\text { R }\end{array}$ & 0.558 & -0.150 \\
\hline $\begin{array}{c}\text { ICS } \\
\text { R }\end{array}$ & -0.359 & 1.000 \\
\hline $\begin{array}{c}\text { PS } \\
\text { R }\end{array}$ & 0.937 & -0.358 \\
\hline
\end{tabular}

\subsection{Composite Reliability}

Table 5. Composite Reliability $\mathrm{H} 2$

\begin{tabular}{|c|c|}
\hline Variable & $\begin{array}{c}\text { Average Variance } \\
\text { Extracted (AVE) }\end{array}$ \\
\hline $\begin{array}{c}\text { Islamic Corporate Social } \\
\text { Responsibility }\end{array}$ & 1.000 \\
\hline Financial Performance & 0.566 \\
\hline
\end{tabular}

Based on the calculation above it can be concluded that

The variable has a quality that is not "deterred. This is indicated by the immovable quality of the composite

\begin{tabular}{|c|c|c|c|c|c|}
\hline Variabel & $\begin{array}{l}\text { Sa } \\
\text { mpe } \\
1 \\
\text { Asli } \\
\text { (O) }\end{array}$ & $\begin{array}{l}\text { Rata- } \\
\text { rata } \\
\text { Samp } \\
\text { el } \\
\text { (M) }\end{array}$ & $\begin{array}{c}\text { Standa } \\
\text { r } \\
\text { Devias } \\
\text { i } \\
\text { (STD } \\
\text { EV) } \\
\end{array}$ & $\begin{array}{c}\mathrm{T} \\
\text { Statist } \\
\text { ik } \\
(\mid \mathrm{O} / \mathrm{S} \\
\mathrm{TDE} \\
\mathrm{V} \mid) \\
\end{array}$ & $\begin{array}{l}\text { P } \\
\text { V } \\
\text { al } \\
\text { ue } \\
\text { s }\end{array}$ \\
\hline $\begin{array}{c}\text { Intellectual } \\
\text { capital - > } \\
\text { Commercial } \\
\text { Banks Financial } \\
\text { Performance } \\
\end{array}$ & $\begin{array}{c}- \\
0.27 \\
9\end{array}$ & $\begin{array}{c}- \\
0.335\end{array}$ & 0.102 & 2.748 & $\begin{array}{c}0 . \\
0 \\
0 \\
7\end{array}$ \\
\hline
\end{tabular}

which is valued above 0.50 as the recommended size.

\subsection{Reliability Test with Composite Reliability}

Determining the composite reliability test, if the composite reliability value is $>0.8$ it can be said that the construct has high reliability or is reliable and $>0.6$ is said to be quite reliable.

Tabel 6. Cronbanch alpha

\begin{tabular}{|c|c|c|}
\hline Variable & $\begin{array}{c}\text { Composite } \\
\text { Reliability }\end{array}$ & $\begin{array}{c}\text { Informa } \\
\text { tion }\end{array}$ \\
\hline Intellectual capital & 1.000 & $\begin{array}{c}\text { Very } \\
\text { Reliabl } \\
\mathrm{e}\end{array}$ \\
\hline $\begin{array}{c}\text { Islamic Corporate Social } \\
\text { Responsibility }\end{array}$ & $\begin{array}{c}\text { Very } \\
\text { Reliabl } \\
\mathrm{e}\end{array}$ \\
\hline Financial Performance & 1.000 & $\begin{array}{c}\text { Reliabl } \\
\mathrm{e}\end{array}$ \\
\hline
\end{tabular}

From the measurement results above, two latent variables have a composite reliability value $>0.8$, and one variable $>0.61$ means that all independent latent variables Intellectual capital (IC) and Islamic Corporate Social Responsibility (ICSR) are appropriate and feasible to be tested variables to determine their effect. On the dependent latent variable, namely the Financial Performance of Syrian Commercial Banks.

\subsection{Designing the Inner Model}

Table 7. R Square

\begin{tabular}{|c|c|c|}
\hline Variabel & R Square & Adjusted R Square \\
\hline $\begin{array}{c}\text { Financial } \\
\text { Performance }\end{array}$ & 0.208 & 0.154 \\
\hline
\end{tabular}

From the R Square table above, the estimated R Square is 0.208 . The results of this $\mathrm{R}$ Square can be clarified that the influence of the variable Intellectual Capital (X1) and Islamic Corporate Social Responsibility (X2) provides an estimate of 0.208 which can be explained that " by the independent latent variable is $20.8 \%$, while $80.2 \%$ is explained by other variables outside of the study. this . From these numbers, it can be categorized that the dependent variable can be explained by an independent variable with a moderate scale.

\subsection{Hypothesis Testing}

\subsubsection{Hypothesis Testing 1}

The influence of "variable Intellectual capital against variable Financial Performance of Commercial Bank " Sharia (Islamicity Performance Index).

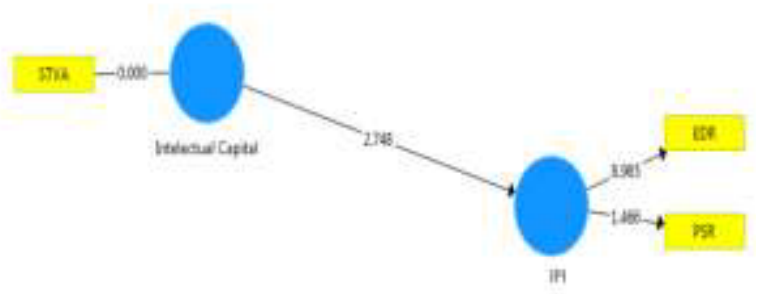

Fig. 6. Bootstrapping H1 
The t-table value is 2.042 and the t-statistic is 2.748 . The measurement results show that t-statistic $>\mathrm{t}$-table so that Intellectual capital (IC) has a positive and significant influence on Dependent Variable Y Financial Performance of Islamic Commercial Banks (Islam city Performance Index).

\subsubsection{Hypothesis Testing 2}

The Influence of "Islamic Corporate Social Responsibility Variables on the Financial Performance of Commercial Banks" Sharia (Islam city Performance Index).

T-table 2.042 and t-statistics 1.782. The measurement results showed that the t-statistic $<\mathrm{t}$-table so that Islamic Corporate Social Responsibility is not impact and not significant against Dependent Variable $\mathrm{Y}$ Financial Islamic Banks (Islam city Performance Index).

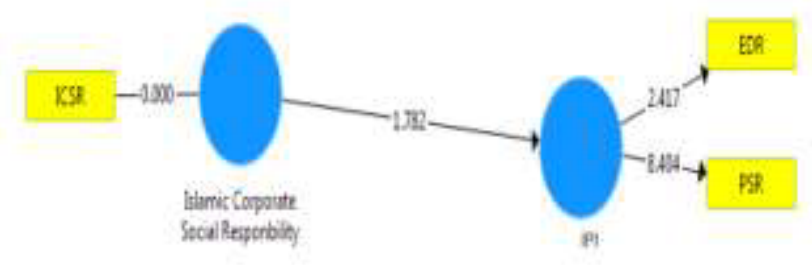

Fig. 7. Bootstrapping $\mathrm{H} 2$

Table 8. Bootstrapping Hypothesis 2

\begin{tabular}{|c|c|c|c|c|c|}
\hline Variabel & $\begin{array}{c}\text { Ori } \\
\text { gina } \\
1 \\
\mathrm{Sa} \\
\mathrm{mpl} \\
\mathrm{e}\end{array}$ & $\begin{array}{l}\mathrm{Sa} \\
\mathrm{mpl} \\
\mathrm{e} \\
\text { Ave } \\
\text { rage }\end{array}$ & $\begin{array}{c}\text { Stan } \\
\text { dard } \\
\text { Dev } \\
\text { iasi }\end{array}$ & $\begin{array}{l}\mathrm{T} \\
\text { St } \\
\text { ati } \\
\text { sti } \\
\text { cs }\end{array}$ & $\begin{array}{l}\mathrm{P} \\
\mathrm{V} \\
\mathrm{al} \\
\mathrm{u} \\
\mathrm{es}\end{array}$ \\
\hline $\begin{array}{c}\text { Islamic Corporate Social } \\
\text { Responsibility -> } \\
\text { Financial Performance } \\
\text { of Islamic Commercial } \\
\text { Banks } \\
\end{array}$ & $\begin{array}{c}- \\
0.3 \\
59\end{array}$ & $\begin{array}{c}- \\
0.3 \\
75\end{array}$ & $\begin{array}{c}0.20 \\
2\end{array}$ & $\begin{array}{c}1 . \\
78 \\
2\end{array}$ & $\begin{array}{l}0 . \\
0 \\
7 \\
8\end{array}$ \\
\hline
\end{tabular}

\section{Conclusion}

Based on the test results, the following conclusions can be drawn:

1. Variable independent (X1) Intellectual capital indicators Structural Capital Value Added (STVA) has a positive effect on draft significantly on Financial Performance Islamic Banks (Islam city Performance Index) indicator Equitable Distribution Ratio (EDR) and Profit Sharing Ratio (PSR).

2. The independent variable (X2) Islamic Corporate Social Responsibility (ICSR) tubs unaffected and significantly to Financial Performance Islamic Banks (Islam city Performance Index) indicator Equitable Distribution Ratio (EDR ) and Profit Sharing Ratio (PSR).
Acknowledgments. This research was aided by fellow lecturers and students, so we sincerely thank you for publishing a journal that will benefit Islamic banking and future researchers.

\section{References}

1. H. Farag, C. Mallin, K. Ow-yong, J. Econ. Behav. Organ, (2014).

2. A. A. Jalil, R. A. Rahman, Institutional investors and earnings management : Malaysian evidence, 8(2), (2010)

3. T. Beck, A. Demirgüç-kunt, O. Merrouche, J. Bank Finan., 37, 2 (2013).

4. S. Ali, M. Ullah, Int. J. Econ. Manag, 05, 03 (2016).

5. W. Djuanda, A. R. Tanjung, Kamaliah, J. Ekon., 27, 3 (2019).

6. P. RI, Undang-undanG Republik Indonesia Tentang Perbankan Syariah 1998, (2008)

7. OJK., ShariA Banking Statistics, (2020).

8. D. Supriyadi, Strategi MEningkatkan Kinerja Perbankan Syariah Melalui Value Added Creation Intelectual, (2019).

9. D. Aditiasari, https://finance.detik.com/moneter/d3076959/7-hambatan-yang-buat-bank-syariahlambat-berkembang-di-ri, (2015).

10. S. Suroso, T. Widyastuti, M. N. Salim, I. Setyawati, International Journal of Economics and Financial Issues, 7, 4, (2017).

11. A. D. Cahyati, JRAK, 3, 1 (2012).

12. D. R. Wijayani, Kompartemen: Jurnal Ilmiah Akuntansi, 17, 1 (2017).

13. W. Kholilah, Pengaruh Intellectual Capital Dan Islamic Corporate Governance Terhadap Kinerja Perbankan Syariah Indonesia, (2019).

14. D. Dinaroe, I. Mulya, E.Mutia, JPED, 5, 1 (2019).

15. H. N. Husna, Pengaruh Islamic Corporate SOCIAL Responsibility Terhadap Reputasi (2020).

16. Gustani. J. Chem. Inf. Model (2017).

17. I. Sidik, Pengaruh zakat dan Islamic Corporate Social responbility (ICSR) terhadap reputasi dan kinerja perusahaan. 1-82 (2016).

18. Khairiyani, Islamic Corporate Social Responsibility terhadap Kinerja Keuangan dan Nilai Perusahaan, 8, 2, (2020)

19. R. S. Hanafi, Dampak Islamic Corporate Governance, Islamic Social Reporting Pada Kinerja Keuangan Bank Syariah di Indonesia, 8, 2 (2019).

20. A. A. Afandi, N. W. N. Supaijo, JIMAT, 7, (2019).

21. N. Hidayanti, Pengaruh intelectul capital dan penerapan islamic corporate governance terhadap kinerja keuangan bank umum syariah di indonesia berdasarkan islamicity performance index. 6 (2017). 
22. S. Hameed, A. Wirman, B. Alrazi, M. Nazli, S.

Pramono, Alternative Disclosure and Performance Measures for Islamic Banks. Second Conference

on Administrative Sciences: Meeting the

Challenges of the Globalization Age, King Fahd

University of Petroleum \& Minerals, Dhahran,

Saudi Arabia, 19-21 (2004).

23. Anggraini, D. Yuni R. Kartika, J. Akun.

Keuangan Islam, 3, 1 (2019). 